П'ятка Н. С., здобувач (Національний університет водного господарства та природокористування, м. Рівне)

\title{
СВІТОВА ПРАКТИКА ЕКОЛОГІЧНОГО ОПОДАТКУВАННЯ ЯК ЗАСІБ СТИМУЛЮВАННЯ ІНВЕСТИЦІЙНОЇ ДІЯЛЬНОСТІ
}

Проаналізовано досвід розвинених країн світу щодо особливостей екологічного оподаткування. Проведено аналіз динаміки та структури основних показників екологічного оподаткування в Європейському Союзі. Виокремлено основні категорії податків, що належать до екологічних у країнах Європейського Союзу. Систематизовано основні екологічні платежі, що використовуються в зарубіжних країнах, а також проведено співставлення з вітчизняними платежами. На прикладі зарубіжного досвіду екологічного оподаткування, розглянуто його фіскальне та стимулююче значення. Виділено дієві інструменти державного регулювання у сфері охорони навколишнього природного середовища.

Ключові слова: екологічне оподаткування, екологічні податки, платежі та збори, стимулювання, інвестиції, зарубіжний досвід, природоохоронна діяльність, навколишнє природне середовище, фінансування природоохоронної діяльності.

В умовах загострення екологічних суперечностей як в глобальному, так і в національному масштабі важливого значення набуває формування сучасних методів раціоналізації природокористування. Як показує світова практика, досягти проривних результатів стосовно уповільнення деградаційних процесів у сфері природокористування можна за умови наявності комплексу методів, засобів, інструментів та важелів фінансового впливу на суб'єкти господарської діяльності, які здійснюють залучення природних ресурсів у відтворювальний процес. В процесі інтеграції України до Європейського Союзу $(€ C)$ вкрай актуальним Є дослідження особливостей екологічного оподаткування розвинутих країн світу.

Проблеми щодо теоретичних та практичних аспектів екологічного оподаткування в своїх працях досліджували Б. Буркинський, О. Веклич, В. Вишневський, Т. Галушкіна, В. Глухова, Л. Грановська, А. Гусєв, Б. Данилишин, С. Дорогунцова, Ю. Маковецька, В. Міщенко, Л. Мельник, Т. Омельяненко, Н. Павліха, О. Попова, І. Сторонянська, М. Хвесик, $Є$. Хлобистов та інші вчені. Розглянуті напрацювання нау- 
ковців $є$ підґрунтям для подальших досліджень особливостей екологічного оподаткування в розвинених країнах світу з метою встановлення дієвості та ефективності їх справляння, а також визначення доцільності його застосування як засобу стимулювання інвестиційної діяльності у сфері природоохоронної діяльності.

Метою статті $€$ дослідження світової практики екологічного оподаткування щодо можливостей стимулювання інвестування у сфері природоохоронної діяльності.

Вирішення природоохоронних проблем в більшості держав реалізуються за допомогою екологічних податків, платежів та зборів. У країнах Європи використовуються екологічні податки як засіб впливу на поведінку суб'єктів господарювання незалежно від того чи належать води до виробників чи до споживачів певних благ. ЄС надає перевагу податковим інструментам впливу, оскільки вони забезпечують гнучкі та економічно вигідні засоби для посилення принципу «забруднювач платить» та реалізації цілей екологічної політики. Екологічні податки накопичують доходи, які можуть бути використані для збільшення витрат на охорону навколишнього природного середовища.

У $€ C$ екологічний податок $€$ податком, основою якого $€$ фізична одиниця об'єкту, що має доведений, специфічний негативний вплив на навколишнє середовище. Збір даних про екологічні податки за видами економічної діяльності $є$ частиною Директиви ЄС № 691/2011 щодо європейських екологічних економічних рахунків Європейського Парламенту та Ради від 6 липня 2011 р., яка забезпечує основу для розробки різних видів екологічних рахунків. У країнах $Є C$ основною функцією екологічного оподаткування $€$ регулювання діяльності економічних суб'єктів, щоб їхня діяльність спричиняла менше навантаження на навколишнє природне середовище. Для деталізації проблеми проаналізуємо міжнародні дані щодо надходжень екологічного податку в ЄС, його частки в загальній сумі податкових надходженнях та співвідношення 3 валовим внутрішнім продуктом (ВВП) (табл. 1).

У 2017 році в ЄС було зібрано 369 млрд євро екологічного податку, що склало $5,9 \%$ у загальній сумі доходів від податків та зборів та становить $2,4 \%$ у порівнянні з ВВП ЄС. Таким чином загальний обсяг екологічного податку в ЄС протягом досліджуваного періоду демонструє стійку тенденцію до зростання, хоча і зазнавав деяких коливань проте зріс на 21,3\% у 2017 р. порівняно із 2010 р. 
Показники екологічного оподаткування в ЄС за 2010-2017рp.

\begin{tabular}{|c|c|c|c|c|c|c|c|c|}
\hline \multirow{2}{*}{ Показники } & \multicolumn{8}{|c|}{ Рік } \\
\hline & 2010 & 2011 & 2012 & 2013 & 2014 & 2015 & 2016 & 2017 \\
\hline \multirow{2}{*}{$\begin{array}{c}\text { Загальні еколо- } \\
\text { гічні податки, } \\
\text { млн євро: } \\
\text { ЄС - } 28 \\
\text { Єврозона } \\
\text { (19 країн) }\end{array}$} & 304063 & 317127 & 327511 & 332668 & 344119 & 360146 & 364780 & 368796 \\
\hline & 217602 & 229557 & 235135 & 240130 & 245751 & 251161 & 259858 & 265579 \\
\hline \multirow{2}{*}{$\begin{array}{c}\text { у \% до загальної } \\
\text { суми податкових } \\
\text { надходжень } \\
€ С-28 \\
\text { Єврозона } \\
\end{array}$} & 6,17 & 6,18 & 6,16 & 6,13 & 6,14 & 6,13 & 6,11 & 5,97 \\
\hline & 5,81 & 5,89 & 5,86 & 5,84 & 5,84 & 5,79 & 5,83 & 5,72 \\
\hline \multirow{2}{*}{$\begin{array}{c}\text { у \% до ВВП } \\
€ С-28 \\
\text { Єврозона }\end{array}$} & 2,37 & 2,4 & 2,43 & 2,45 & 2,45 & 2,43 & 2,44 & 2,4 \\
\hline & 2,28 & 2,34 & 2,39 & 2,41 & 2,42 & 2,38 & 2,4 & 2,37 \\
\hline
\end{tabular}

Джерело: складено автором на основі [1; 2]

Слід зазначити, що попри зростання загальних обсягів екологічного податку у 2017 році до 368796 млн євро це лише $2,4 \%$ ВВП і 6,2\% від усіх податкових платежів і соціальних внесків, що характеризує таки не високу дохідність. Для чіткого відображення динаміки обсягів екологічного податку та його частки у загальній суми податкових надходжень побудуємо графік (рис. 1).

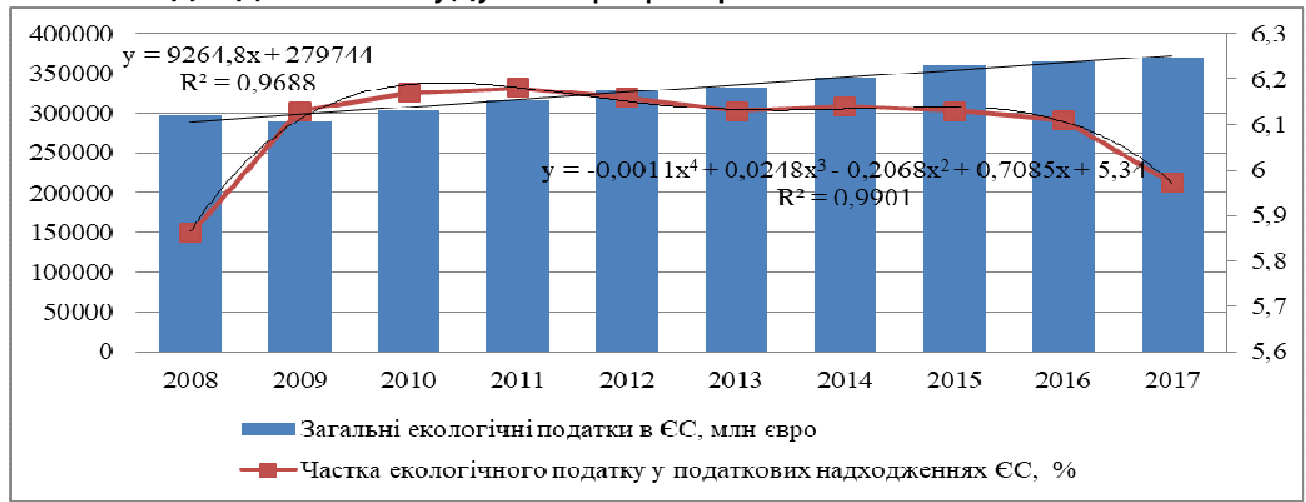

Рис. 1. Динаміка частки екологічного податку у податкових надходженнях ЄС за період від 2008 до 2017 рр., млн євро

Джерело: побудовано автором на основі [1; 2]

Загалом протягом досліджуваного періоду обсяги екологічного податку в ЄС стабільно заростали на 9264,8 євро щорічно, що також підтверджує отриманий коефіцієнт детермінації ( $\mathrm{R} 2=0,9688)$, значення якого свідчить про те, що 96,88\% щорічної варіації коефіцієнту 
покриття пов'язана з варіацією основних чинників, що відображають загальну тенденцію рівня екологічного податку, а лише $3,12 \%$ припадає на інші випадкові чинники.

Для того, щоб не враховувати вплив зміни валютного курсу, варто розглянути частку екологічного податку у податкових надходженнях ЄС, найвище значення якої спостерігалось у 2011 р. (6,18\%) та виявлено чітку тенденцію до її зменшення, проте не можна однозначно стверджувати, що ця тенденція $є$ негативною, оскільки це середнє значення, а в розрізі країн динаміка дещо відрізняється. Варто зазначити, що частка екологічного податку у податкових надходженнях бюджету в Україні в рази менша - 0,5-1,3\%, при тому як в інших країнах ЄС цей показник коливається у межах 4-12\%. До прикладу Найбільшу частку має Латвія (11,2\%), Словенія і Греція (по 10,2\%), Хорватія та Болгарія (по 9,1\%). Найменше грошей екологічний податок приносить Люксембургу (4,4\%), Німеччині (4,6\%), Швеції (4,9\%), Франції та Бельгії (по 5\%), а у Польщі практично 8\% (з якою Україна близька за значення обсягів викидів забруднюючих речовин та кількості утворюваних відходів). Таким чином, можна стверджувати, що екологічні податки не $є$ бюджетоутворюючими податками, оскільки їх частка у загальних податкових надходженнях залишається порівняно незначною та має тенденцію до зменшення.

Важливим показником аналізу екологічних платежів в країнах $€ C \in$ співвідношення надходжень від екологічного податку та ВВП (рис. 2).

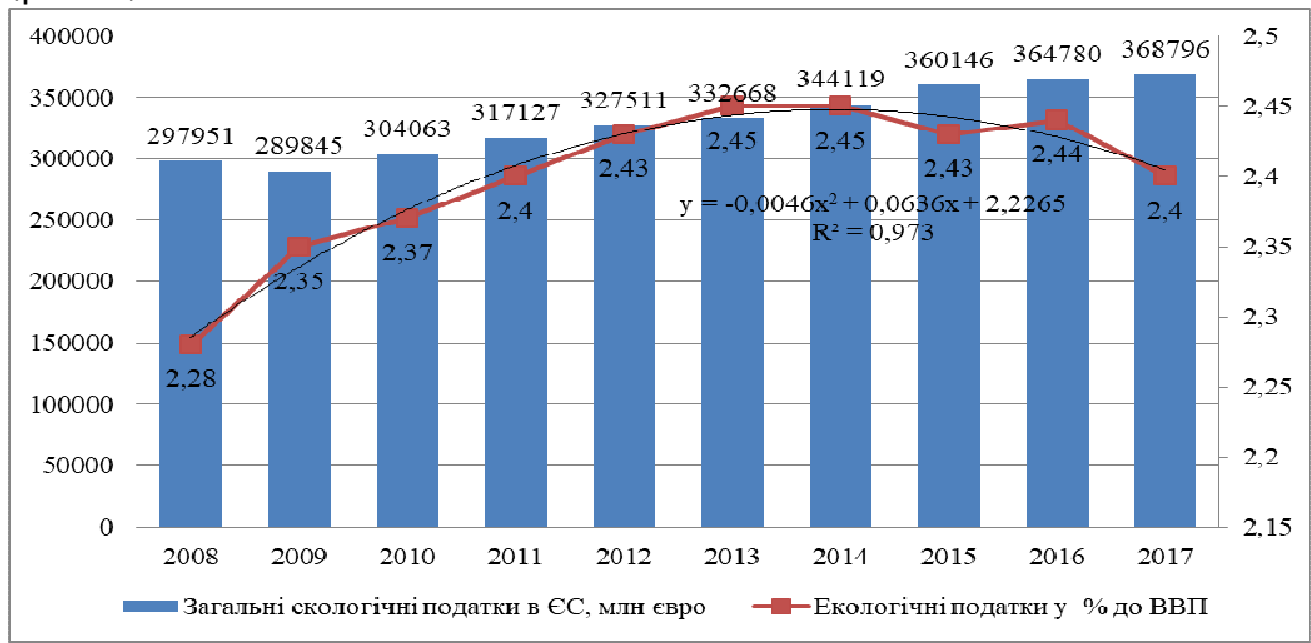

Рис. 2. Динаміка співвідношення надходжень від екологічного податку та ВВП ЄС за період від 2008 до 2017 рр., млн євро

Джерело: побудовано автором на основі [1; 2] 
Загалом екологічні податки у \% до ВВП перебувають на рівні від 2,2 до 2,5\% за весь досліджуваний період. Натомість в Україні за аналізований період на рівні від 0,06 до 1,6 \% [3], при чому у 2017 0,06\% ці цифри відрізняються від європейських на порядок, тобто, можна сказати, що в Україні екологічний податок надзвичайно низький. 3 екологічних податків в ЄС на природоохоронні заходи витрачається лише $0,8 \%$ ВВП, а решта - на дослідження та попередження, що справді мотивує інвестувати, щоб менше забруднювати і, відповідно, менше платити. Насправді збереження та відтворення навколишнього природного середовища потребує певних наукових і технічних знань, які б дали змогу приймати рішення, які $€$ інформаційно обґрунтованими, досяжними і прийнятними. У розвинених країнах світу існує широка мережа моніторингу довкілля та наукових інституцій, що $є$ незалежними (Німеччинина), або входять до складу органів екологічного регулювання (США). В інших країнах (Франція, Німеччина, Великобританія, Нідерланди) також існують наукові заклади, які на замовлення агентств охорони довкілля виконують екологічні дослідження, зокрема розробку «зелених» технологій.

Проаналізований досвід країн ЄС демонструє, що під екологічними податками, які з року в рік становлять все більш значну частину дохідної бази бюджетів цих країн, розуміють саме податки на небезпечні для навколишнього середовища види господарської діяльності: виробництво енергетичного і моторного палива, електроенергії, автомобілів тощо. Іншими словами, все, що здатне викликати несприятливі зміни в навколишньому середовищі, може бути предметом екологічного оподаткування. Дані про екологічні податки у статистиці ЄС подаються у розрізі наступних категорій: податків на енергію; транспорт; забруднення та ресурси [4] (табл. 1).

Таблиця 1

Класифікація екологічних податків у країнах ЄС

\begin{tabular}{|c|c|c|}
\hline $\begin{array}{l}\text { № } \\
3 / \pi\end{array}$ & $\begin{array}{c}\text { Категорії по- } \\
\text { датків }\end{array}$ & Види та компоненти податків \\
\hline \multirow{3}{*}{1} & \multirow{3}{*}{$\begin{array}{l}\text { Енергія } \\
\text { (включаючи } \\
\text { паливо для } \\
\text { транспорту) }\end{array}$} & $\begin{array}{c}\text { Енергетичні податки для транспортних цілей (неочищений } \\
\text { бензин; бензини з свинцем; дизельне паливо; інші енерге- } \\
\text { тичні продукти для транспортних цілей (наприклад, LPG, } \\
\text { природний газ, керосин або мазут)). }\end{array}$ \\
\hline & & $\begin{array}{c}\text { Енергетичні податки для стаціонарних цілей (легкий мазут; } \\
\text { мазут; природний газ; вугілля; кокс; біопаливо; споживання } \\
\text { та виробництво електроенергії; територіальне споживання } \\
\text { та виробництво тепла; інші енергетичні продукти для стаці- } \\
\text { онарного використання). }\end{array}$ \\
\hline & & $\begin{array}{c}\text { Парникові гази(вміст вуглецю в паливі; викиди парникових } \\
\text { газів (включаючи надходження від дозволів на викиди, що } \\
\text { фіксуються як податки в національних рахунках)). }\end{array}$ \\
\hline
\end{tabular}


продовження табл. 1

\begin{tabular}{|c|c|c|}
\hline \multirow{7}{*}{2} & \multirow{7}{*}{$\begin{array}{l}\text { Транспорт } \\
\text { (крім палива } \\
\text { для транспо- } \\
\text { рту) }\end{array}$} & $\begin{array}{c}\text { Імпорт або продаж автотранспортних засобів (одноразові } \\
\text { податки) }\end{array}$ \\
\hline & & $\begin{array}{c}\text { Реєстрація або використання транспортних засобів, періо- } \\
\text { дичні (наприклад, щорічні податки) }\end{array}$ \\
\hline & & Використання доріг (наприклад, податки на автомагістралі) \\
\hline & & $\begin{array}{c}\text { Збори за перевантаження доріг та міські збори (якщо пода- } \\
\text { тки в національних рахунках) }\end{array}$ \\
\hline & & Інші транспортні засоби (кораблі, літаки, залізниці тощо) \\
\hline & & Рейси та авіаквитки \\
\hline & & $\begin{array}{c}\text { Страхування транспортних засобів (не враховує загальні } \\
\text { збори страхування) }\end{array}$ \\
\hline \multirow{6}{*}{3} & \multirow{6}{*}{ Забруднення } & $\begin{array}{c}\text { Виміряні або розрахункові викиди в атмосферне повітря } \\
\text { (виміряні або оцінені викиди NO х ; виміряні або оціне- } \\
\text { ні викиди SO х; інші виміряні або розрахункові викиди в ат- } \\
\text { мосферне повітря (за винятком } \mathrm{CO}_{2} \text { ) }\end{array}$ \\
\hline & & Озоноруйнуючі речовини \\
\hline & & $\begin{array}{c}\text { Виміряні або оцінені стоки (виміряні або розрахункові від- } \\
\text { ходи окиснювальних речовин ; інші виміряні або оцінені } \\
\text { стоки; збір та очищення стічних вод, фіксовані щорічні по- } \\
\text { датки) }\end{array}$ \\
\hline & & $\begin{array}{c}\text { Неточкові та непрямі джерела забруднення води (пестици- } \\
\text { ди (на основі, наприклад, хімічного складу, ціни або обсягу); } \\
\text { штучні добрива (на основі, наприклад, вмісту фосфору або } \\
\text { азоту або ціни); гній) }\end{array}$ \\
\hline & & $\begin{array}{c}\text { Поводження з відходами (збір, обробка або утилізація; ін- } \\
\text { дивідуальні продукти (наприклад, упаковка, контейнери } \\
\text { для напоїв, батареї, шини, мастильні матеріали)) }\end{array}$ \\
\hline & & Шум (наприклад, зліт і посадка літаків) \\
\hline \multirow{4}{*}{4} & \multirow{4}{*}{ Ресурси } & Водозабір \\
\hline & & $\begin{array}{c}\text { Збирання біологічних ресурсів (наприклад, деревина, по- } \\
\text { лювання та вилов риби) }\end{array}$ \\
\hline & & Видобуток сировини (наприклад, мінералів, нафти та газу) \\
\hline & & Зміна ландшафтів та зрізання дерев \\
\hline
\end{tabular}

Джерело: складено автором на основі [4]

Загалом в зарубіжних країнах застосовують близько 500 різновидів екологічних податків та зборів, зокрема: плата за забруднення водних об'єктів (Німеччина, Австрія, Франція, Данія, Чехія, Словенія), податок за викиди вуглекислого газу (Данія, Норвегія, Франція, Фінляндія, Словенія), податок/плата за викиди в атмосферу (Чехія, Франція, Польща), податок на теплові викиди (Данія), податок на продукцію, що містить екологічно шкідливі речовини (Данія, Норвегія, Швеція, Чехія, Франція, Бельгія, Австрія, Словаччина, Німеччина, Латвія, Литва, Польща), податок на упаковку (скло, метал, пластик) 
(Данія, Норвегія, Швеція, Фінляндія), податок за споживання енергії (Данія, Швеція, Німеччина, Нідерланди, Фінляндія), збір за захист навколишнього середовища (Великобританія, Швеція), податок за розміщення відходів на полігонах - всі країни ЄС.

Найбільшого поширення в країнах ЄС набули транспортні та енергетичні податки. В тій чи іншій формі вони введені у всіх країнах-членах Європейського Союзу. Слід відзначити, що транспортні та енергетичні податки за своєю суттю $€$ фіскальними, тобто вводяться з метою отримання доходів. Позитивний же ефект для навколишнього середовища в даному випадку є супутнім.

Досить розповсюдженою $є$ практика плати за зворотні викиди це економічний інструмент екологічної політики, що передбачає спрямування коштів зі спеціальних фондів підприємствам, які за рахунок науково-технічного прогресу змогли зменшити кількість шкідливих викидів у навколишнє природне середовище. Це не лише веде до зменшення викидів, але й заохочує до впровадження нових технологій на підприємствах. У Швеції плата за зворотні викиди дала змогу зменшити викиди в атмосферне повітря на 50 відсотків.

В усьому світі надзвичайно важливими $є$ викиди парникових газів, зокрема двоокису вуглецю. За даними Світового банку, система оподаткування двоокису вуглецю у тій чи іншій формі запроваджена більш як у 40 країнах і 20 окремих юрисдикціях (містах, штатах, регіонах): США, Китаї, європейських країнах, Австралії. Ставки податку на викиди двоокису вуглецю (у 2017 році) у світі варіюються в діапазоні від 1 до 150 дол. США/т, в Україні - 0,33 грн/тонну (Індія 1,07 дол. США/т, Китай, Канада - 3,5-15 дол. США/т, Данія, Словенія -13 євро/т, Великобританія - 16 євро/т, Нідерланди, Фінляндія 20 євро/т, Німеччина - 25 євро/т, Швеція - 150 дол. США/тонну) [5].

Слід відзначити особливу роль у країнах $€ C$ податків на продукт (продуктових податків) у регулюванні рівня екологічної безпеки. До екологічних податків на продукт належать податки, що стягуються 3 одиниці готової продукції, яка на одному з етапів свого життєвого циклу призводить до забруднення довкілля. Податки на продукт найчастіше встановлюються для автомобільних шин, батарейок та акумуляторів, миючих засобів, пластикової упаковки та багатьох інших товарів. Стимулююча функція цих податків реалізується шляхом збільшення ціни за рахунок податку, що призводить до зменшення споживання цієї продукції. Так, наприклад, в Австрії введення платежів за використання пестицидів та мінеральних добрив знизило їх споживання на $30 \%$ [5; 4]. Запровадження такого виду екологічних податків $є$ актуальним для України. 
Деякі види екологічних податків, які стягуються у країнах ЄC, співпадають з компонентами екологічного податку в Україні. Так, податки за забруднення і частково енергетичні податки в ЄС та такі компоненти екологічного податку в Україні як податок за забруднення атмосферного повітря, скиди забруднюючих речовин у водні об'єкти, розміщення відходів, податок за обсяги електричної енергії, виробленої експлуатуючими організаціями ядерних установок (атомних електростанцій).

Натомість деякі екологічні податки ЄС включають такі види податків, які в Україні існують окремо від екологічного: транспортні податки і податки на ресурси в ЄС та рентна плата за спеціальне використання лісових ресурсів, води, користування надрами тощо в Україні. Також спостерігаємо відсутність у системі державного екологічного оподаткування України податків на шумове забруднення і продуктових податків. Саме тому виникають труднощі щодо забезпечення порівнюваності екологічних податків $Є С$ та екологічного податку в Україні.

Таким чином, можна стверджувати, що в світі не існує єдиної уніфікованої системи обов'язкових платежів, що пов'язані з навколишнім природним середовищем та загальні екологічні податки $Є C$ охоплюють набагато ширше коло обов'язкових платежів, ніж поняття «екологічний податок» за нормами вітчизняного законодавства, в кожній країні застосовуються різні механізми фінансово-економічного характеру вирішення проблем охорони навколишнього природного середовища. Основні екологічні платежі, що використовуються в деяких зарубіжних країнах систематизовано у табл. 2.

Досвід країн ЄС свідчить про те, що причини дієвості екологічних податків за забруднення в країнах полягають у високих ставках, які спрямовані на те, щоб підприємствам було вигідніше здійснювати заходи з охорони довкілля, а не забруднювати його. Водночас країнами ЄС широко використовується практика застосування підвищених ставок за понадлімітне забруднення, крім того, деякими з них встановлено не лише коефіцієнти кратності за таке забруднення, а й взагалі оподаткування здійснюється за прогресивною шкалою: чим більше викидів, тим вища ставка екологічного податку. 
Основні екологічні платежі, що використовуються в зарубіжних

Країнах

\begin{tabular}{|c|c|c|c|c|c|c|c|c|c|}
\hline \multirow[b]{2}{*}{ Податки, платежі та збори } & \multicolumn{9}{|c|}{ Країни } \\
\hline & 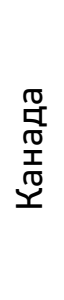 & 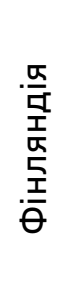 & 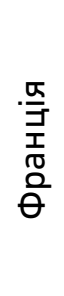 & 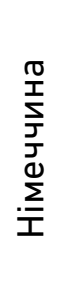 & $\begin{array}{l}. \frac{\text { 号 }}{5} \\
\text { 上 }\end{array}$ & 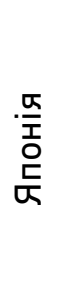 & $\begin{array}{l}\text { 哥 } \\
\text { d } \\
\text { 荨 }\end{array}$ & 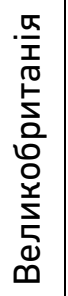 & 多 \\
\hline \multirow{4}{*}{$\begin{array}{c}\text { Плата за забруднення: } \\
\text { - атмосферного повітря; } \\
\text { - води; } \\
\text { - відходами; } \\
\text { - шумом }\end{array}$} & & & + & & & + & & & \\
\hline & & & + & + & + & & & & \\
\hline & & & & & & & & & + \\
\hline & & & + & + & & + & & + & + \\
\hline $\begin{array}{c}\text { Платежі за збір та переробку від- } \\
\text { ходів }\end{array}$ & + & + & + & + & + & + & + & + & + \\
\hline $\begin{array}{c}\text { Екологічний податок на продукт, } \\
\text { що включений в ціну продукції }\end{array}$ & & + & + & + & + & & + & & + \\
\hline Адміністративні платежі (ліцензії) & & + & + & + & + & + & + & + & + \\
\hline Субсидії & + & + & + & + & & + & + & & + \\
\hline Екологічне страхування & & & + & & + & + & + & + & + \\
\hline
\end{tabular}

Джерело: складено автором на основі $[1 ; 4 ; 6 ; 7]$

Досвід розвинутих країн показує, що використання зазначених екологічних податків, платежів та зборів стимулює розвиток еколого-орієнтованих виробництв і видів діяльності, обмежує розвиток небезпечних технологій, акумулює кошти для цільового вирішення природоохоронних проблем.

Загалом в економічно розвинутих країнах активно працює механізм стимулювання: пряма дотація очисних та інших видів обладнання природоохоронного призначення; будівництво міських та районних водоочисних споруд, які позбавляють підприємства від відповідних витрат; пільгове цільове кредитування приватного сектора; система податкових пільг і т.п. Паралельно із стимулюванням застосовуються також і важелі примусу, дія яких спрямована на порушників цілісності навколишнього природного середовища (заборона виробництва, будь-яких хімічних речовин, що володіють підвищеною токсичністю, вимога про припинення викидів у навколишнє природне середовище залишкових продуктів в місцях і районах, де склало- 
ся критичне становище з точки зору стану навколишнього середовища). У деяких країнах для забруднюючих середовище підприємств установлюється обов'язок виплачувати в бюджет прогресивний податок за «наднормативні» викиди забруднюючих та інших шкідливих речовин. Ряд законодавчих систем передбачає штрафи в разі недотримання встановлених екологічних норм, а в окремих випадках - позбавлення волі порушників законів чи заборона діяльності підприємств [7].

Таким чином, в економічно розвинутих країнах екологічний податок використовується з метою впливу на поведінку суб'єктів господарювання, як виробників, так і споживачів.

В результаті проведеного огляду світової практики екологічного оподаткування стало зрозуміло, що екологічні податки в зарубіжних країнах виконують обидві основні функції: стимулюючу (заохочують природоохоронну діяльність підприємств) і фіскальну (спрямовуються на компенсацію заподіяного збитку шляхом фінансування природоохоронної діяльності), тобто стимулюють проведення природоохоронної політики, а також наповнюють доходи бюджету.

Практика розвинутих країн доводить, що витрати на наукові дослідження, які фінансуються за рахунок екологічного податку дають змогу одержати значну економію коштів при здійсненні природоохоронних заходів та істотно зменшити збитки від забруднення і виснаження компонентів навколишнього природного середовища .

Досвід розвинутих країн світу свідчить про те, що причини дієвості екологічних податків за забруднення полягають у високих ставках, які спрямовані на те, щоб підприємствам було вигідніше вживати заходи з охорони навколишнього природного середовища, а не забруднювати його. Головна особливість податкового екологоекономічного засобу полягає в тому, що зібрані таким способом кошти надходять на бюджетні рахунки відповідного рівня і використовуються здебільшого на фінансування наукових досліджень та попередження шкідливих викидів у навколишнє середовище, що справді мотивує інвестувати, щоб менше забруднювати i, відповідно, менше платити.

1. Eurostat. Environmental protection expenditure in Europe. Electronic resource. URL: http://appsso.eurostat.ec.europa.eu (дата звернення: 15.05.2019). 2. Eurostat. GDP and main components (output, expenditure and income). URL: http://appsso.eurostat.ec.europa.eu (дата звернення: 15.05.2019). 3. Державний комітет статистики України. URL: http://ukrstat.org/ (дата звернення: 15.05.2019). 4. Environmental taxes. Eurostat. URL: http://ec.europa.eu/eurostat/web/environment /environmental 
-taxes. (дата звернення: 15.05.2019). 5. OECD/EEA Database on instruments used for environmental policy and natural resources management. URL: http://www2. oecd.org/ecoinst/queries. (дата звернення: 15.05.2019). 6. Волковець Т. В. Види екологічних податків, які застосовуються зарубіжними країнами. URL: http://www.essuir.sumdu.edu.ua /bitstream/ 123456789 /11153/1/14.pdf (дата звернення: 15.05.2019). 7. Драган І. О. Аналіз зарубіжного досвіду інвестиційно-інноваційного забезпечення державної екологічної політики. Науковий вісник академії муніципального управління. Наукові розвідки з державного та муніципального управління : зб. наук. пр. К. : Видавничо-поліграфічний центр АМУ, 2011. Вип. 2. С. 50-60.

\section{REFERENCES:}

1. Eurostat. Environmental protection expenditure in Europe. Electronic resource. URL: http://appsso.eurostat.ec.europa.eu (data zvernennia: 15.05.2019). 2. Eurostat. GDP and main components (output, expenditure and income). URL: http://appsso.eurostat.ec.europa.eu (data zvernennia: 15.05.2019). 3. Derzhavnyi komitet statystyky Ukrainy. URL: http://ukrstat.org/ (data zvernennia: 15.05.2019). 4. Environmental taxes. Eurostat. URL: http://ec.europa.eu/eurostat/web/environment /environmental -taxes. (data zvernennia: 15.05.2019). 5. OECD/EEA Database on instruments used for environmental policy and natural resources management. URL: http://www2. oecd.org/ecoinst/queries. (data zvernennia: 15.05.2019). 6. Volkovets T. V. Vydy ekolohichnykh podatkiv, yaki zastosovuiutsia zarubizhnymy krainamy. URL: http://www.essuir.sumdu.edu.ua /bitstream/ 123456789 111153/1/14.pdf (data zvernennia: 15.05.2019). 7. Drahan I. O. Analiz zarubizhnoho dosvidu investytsiino-innovatsiinoho zabezpechennia derzhavnoi ekolo-hichnoi polityky. Naukovyi visnyk akademii munitsypalnoho upravlinnia. Naukovi rozvidky z derzhavnoho ta munitsypalnoho upravlinnia : zb. nauk. pr. K. : Vydavnycho-polihrafichnyi tsentr AMU, 2011. Vyp. 2. S. 50-60.

Рецензент: к.е.н., професор Ковшун Н. Е. (НУВГП)

Piatka N. S., Applicant (National University of Water and Environmental Engineering, Rivne)

WORLD PRACTICE OF ENVIRONMENTAL TAXATION AS A MEANS TO INCENTIVE INVESTMENT ACTIVITIES

The experience of developed countries of the world regarding the features of environmental taxation is analyzed. The analysis of the dynamics and structure of the main indicators of environmental taxation in the European Union is carried out, as well as their comparison with domestic indicators. The main categories of taxes 
that are environmental in the countries of the European Union are distinguished. The main ecological payments used in foreign countries are systematized, as well as their comparison with domestic taxes, payments and fees. On the example of the foreign experience of environmental taxation, its fiscal and stimulating value is considered. Effective instruments of state regulation in the field of environmental protection have been allocated. Proven expediency of environmental taxation as a means of stimulating investment activity in the field of environmental activities.

Keywords: environmental taxation, environmental taxes, fees and charges, incentives, investments, foreign experience, environmental protection activities, the natural environment, financing environmental protection activities.

Пятка Н. С., соискатель (Национальный университет водного хозяйства и природопользования, г. Ровно)

МИРОВАЯ ПРАКТИКА ЭКОЛОГИЧЕСКОГО НАЛОГООБЛОЖЕНИЯ КАК СРЕДСТВО СТИМУЛИРОВАНИЯ ИНВЕСТИЦИОННОЙ ДЕЯТЕЛЬНОСТИ

Проанализирован опыт развитых стран мира относительно особенностей экологического налогообложения. Проведен анализ динамики и структуры основных показателей экологического налогообложения в Европейском Союзе. Выделены основные категории налогов, относящихся к экологическим в странах Европейского Союза. Систематизированы основные экологические платежи, которые используются в зарубежных странах, а также проведено сопоставление с отечественными платежами. На примере зарубежного опыта экологического налогообложения, рассмотрены его фискальное и стимулирующее значение.

Ключевые слова: экологическое налогообложения, экологические налоги, платежи и сборы, стимулирования, инвестиции, зарубежный опыт, природоохранная деятельность, окружающую природную среду, финансирование природоохранной деятельности. 